\title{
STUDI KUALITAS AIR IRIGASI DUMOGA DI KABUPATEN BOLAANG MONGONDOW PROVINSI SULAWESI UTARA
}

\author{
Oleh \\ Sofia Wantasen; Joudie. N. Luntungan \\ Fakultas Pertanian Universitas Sam Ratulangi Manado \\ Email: swantasen@yahoo.co.id; jnluntungan@yahoo.com
}

\begin{abstract}
Abstrak
Air irigasi berperan sangat penting dan merupakan salah satu kunci keberhasilan peningkatan produksi tanaman padi di lahan sawah. Tujuan dari penelitian ini adalah untuk mengetahui kondisi kualitas air Irigasi Dumoga di Kabupaten Bolaang Mongondow Provinsi Sulawesi Utara. Cara penelitian adalah observasi lapang terhadap aktivitas pertanian dan pengambilan sampel kualitas air irigasi dilakukan dengan menggunakan metode composite sampling di saluran Irigasi Dumoga. Pengukuran in situ $\mathrm{pH}$, dan temperatur. Analisis konsentrasi TDS, TSS, DHL, nitrat, fosfat, natrium, kalsium, dan magnesium dilakukan di laboratorium. Analisis data menggunakan Metode Grafik dan membandingkan dengan Baku Mutu sesuai PP No. 82/2001 Kelas IV, serta analisis data menggunakan perhitungan Sodium Absorption Ratio (SAR)

Hasil penelitian menunjukkan bahwa temperatur air Irigasi Dumoga $29,3^{\circ} \mathrm{C}, \mathrm{pH} 7,12$, TDS $127 \mathrm{mg} / \mathrm{l}$, TSS $7 \mathrm{mg} / \mathrm{l}$, DHL $182 \mu \mathrm{S} / \mathrm{cm}$, Nitrat 0,040 mg/l, Fosfat-total 0,076 mg/l memenuhi syarat sesuai PP No. 82/2001 Kelas IV. Konsentrasi natrium 6,38 mg/l, kalsium 0,76 mg/l, magnesium 0,27 mg/l.

Kata kunci: Kualitas air, Irigasi Dumoga, Kabupaten Bolaang Mongondow

\section{WATER QUALITY STUDYOF DUMOGA IRRIGATIONAT KABUPATEN BOLAANGMONGONDOW PROVINCE SULAWESI UTARA}

oleh

Sofia Wantasen; Joudie. N. Luntungan

Fakultas Pertanian Universitas Sam Ratulangi Manado

Email: swantasen@yahoo.co.id; jnluntungan@yahoo.com
\end{abstract}

\begin{abstract}
Water Irrigation a very important and is one key to the success of the increased production of rice plants in the paddy field. The aim of this study was to assess the water quality Irrigation Dumoga at Kabupaten Bolaang Mongondow Province Sulawesi Utara. Data collected by observation of agriculture activity and determination of sampling by using composite sampling method at canal Irrigation Dumoga. Measurement in situ $\mathrm{pH}$, and temperatur. Analysis concentration total dissolved solid (TDS), total suspended solid (TSS), conductivity (DHL), nitrate and phosphate, sodium, calcium, magnesium in the Laboratory. Method data analysis are Graphic Method and to compare with standart Goverment PP. No. 82/2001 Class IV, and Sodium Absorption Ratio (SAR) Analysis.
\end{abstract}


The results showed that temperatur at canal Irrigation Motabang 29, $3^{\circ} \mathrm{C}, \mathrm{pH} 7,12$, value of the total dissolved solid (TDS) $127 \mathrm{mg} / \mathrm{l}$, total suspended solid (TSS) $7 \mathrm{mg} / \mathrm{l}$, conductivity (DHL) $182 \mu \mathrm{S} / \mathrm{cm}$, nitrate $0,040 \mathrm{mg} / \mathrm{l}$, phosphate $0,076 \mathrm{mg} / \mathrm{l} \mathrm{mg} / \mathrm{l}$ eligible accordance with the standard PP No. 82/2001 Kelas IV. Natrium concentration 6,38 $\mathrm{mg} / \mathrm{l}$, kalsium $0,76 \mathrm{mg} / \mathrm{l}$, magnesium $0,27 \mathrm{mg} / \mathrm{l}$.

Key-words: Water quality, Dumoga Irrigation, Kabupaten Bolaang Mongondow

\section{Pendahuluan}

Air irigasi merupakan air yang penting dalam pertumbuhan dan produksi tanaman padi. Nilai kualitas air irigasi menentukan batasan dan penggunaan air irigasi untuk pertanian, dan juga mengetahui apakah air tersebut tercemar dan tidak baik digunakan sebagai kebutuhan air pertanian. Air irigasi berperan sangat penting dan merupakan salah satu kunci keberhasilan peningkatan produksi tanaman padi di lahan sawah (Firdaus, 2010 dalam Sinaga dkk, 2013).

Baku mutu air adalah ukuran batas atau kadar makhluk hidup, zat, energi, atau komponen yang ada atau harus ada dan atau unsur pencemar yang ditenggang keberadaannya di dalam air (PP Nomor 82 Tahun 2001 tentang Pengelolaan Kualitas Air dan Pengendalian Pencemaran Air). Menurut Peraturan Pemerintah Nomor 82 Tahun 2001 tentang Pengelolaan Kualitas Air dan Pengendalian Pencemaran Air, Klasifikasi mutu air ditetapkan menjadi 4 (empat) kelas :

Klasifikasi mutu air ditetapkan menjadi 4 (empat) kelas yaitu:

a. Kelas satu, air yang peruntukannya dapat digunakan untuk air baku air minum, dan atau peruntukan lain yang mempersyaratkan mutu air yang sama dengan kegunaan tersebut;

b. Kelas dua, air yang peruntukannya dapat digunakan untuk prasarana/sarana rekreasi air, pembudidayaan ikan air tawar, peternakan ,air untuk mengairi pertanaman, dan atau peruntukkan lain yang mempersyaratkan mutu air yang sama dengan kegunaan tersebut;

c. Kelas tiga, air yang peruntukannya dapat digunakan untuk pembudidayaan ikan air tawar, peternakan, air untuk mengairi pertanaman, dan atau peruntukan lain yang mempersyaratkan air yang sama dengan kegunaan tersebut;

d. Kelas empat, air yang peruntukannya dapat digunakan untuk mengairi,pertanaman dan atau peruntukan lain yang mempersyaratkan mutu air yang sama dengan kegunaan tersebut.
Disamping itu, kesesuaian air untuk kepentingan irigasi pertanian dapat diukur dengan parameter Sodium Adsorption Ratio (SAR). Rasio ini menggambarkan sampai sejauh mana natrium akan terserap kedalam tanah. Nilai SAR yang tinggi memperlihatkan bahwa natrium pada air irigasi menggantikan ion kalsium dan dan magnesium dalam tanah dan mengubah struktur tanah. (Effendi 2003).

Klasifikasi air berdasarkan nilai SAR, dibawah dari 10 baik sekali, $10-18$ baik, $18-26$ cukup, diatas 26 kurang baik (Mahida, 1981).

Air berkadar sodium rendah (S1) dapat dipergunakan untuk irigasi pada hampir semua tanah dengan sedikit kemungkinan timbulnya bahaya yang dapat mengembangkan pertukaran sodium (Mahida, 1981).

Air yang berkadar sodium sedang (S2) akan menimbulkan cukup bahaya sodium dalam tanah yang bertekstur halus yang mempunyai kapasitas pertukaran kation yang tinggi, kecuali apabila terdapat gypsum di dalam tanah, tapi air semacam ini dapat dipergunakan dengan baik pada tanah yang bersusunan kasar atau tanah organik dengan daya serap yang baik (Mahida, 1981).

Air yang berkadar sodium tinggi (S3) dapat menimbulkan pertukaran sodium yang berbahaya dalam kebanyakan tanah dan membutuhkan penanganan tanah yang khusus pengaliran air yang baik, pelumeran tinggi, dan penambahan sejumlah zat organik (Mahida, 1981).

Air yang berkadar sodium tinggi sekali (S4) biasanya tidak memuaskan untuk keperluan irigasi, kecuali apabila ia berkadar salinitas rendah dan mungkin sedang, dimana pencairan kalsum tanah atau penggunaan gypsum atau perbaikan lain memungkinkan penggunaan air tersebut menjadi mudah (Mahida, 1981).

\section{Parameter - Parameter Air Irigasi \\ a. Temperatur}

Temperatur berguna dalam memperlihatkan kecenderungan aktifitas- aktifitas kimiawi dan 
biologi, pengentalan, tekanan uap, ketegangan permukaan dan nilai - nilai penjenuhan dari pada benda - benda padat dan gas - gas. Perubahan Temperatur berpengaruh terhadap proses fisika, kimia dan biologi badan air. Peningkatan Temperatur mengakibatkan peningkatan viskositas, reaksi kimia, evaporasi dan volatilisasi (Effendi, 2003).

\section{b. $\mathbf{p H}$}

Kisaran $\mathrm{pH}$ normal untuk air irigasi 5,0 - 9,0 (PP No. 82/2001). Air irigasi dengan kisaran $\mathrm{pH}$ yang ekstrim asam atau basa dapat menyebabkan ketidakseimbangan hara atau mungkin mengandung ion beracun (Ayers and Westcot, 1985). pH menunjukan kadar asam atau basa dalam suatu larutan, keadaan netral ditandai dengan $\mathrm{pH}=7$.

Air untuk irigasi sebaiknya bersifat netral, tidak terlalu asam dan juga tidak terlalu basa. Air irigasi yang asam banyak mengandung ion hidrogen dan air irigasi yang basa banyak mengandung ion hidroksida sehingga dapat mengurangi daya serap zat-zat yang diperlukan tanaman. Selain itu juga dapat merusak sel-sel tanaman sehingga metabolisme dari sel-sel terganggu dan mengurangi daya serap nutrisi.

\section{c. DHL (Daya Hantar Listrik)}

Konduktivitas (Daya Hantar Listrik) adalah gambaran numerik dari kemampuan air untuk meneruskan aliran listrik. Oleh karena itu semakin banyak garam - garam terlarut semakin tinggi pula nilai DHL (Effendi, 2003). Metode penggunaan daya hantar listrik dianggap sebagai prosedur standar untuk menilai kadar garam dari air irigasi.

\section{d $\quad$ Nitrat $\left(\mathrm{NO}_{3}\right)$}

Tanaman padi mempunyai kemampuan untuk menyerap unsur nitrogen dari penggunaan pupuk yang mengandung nitrogen sekitar $20 \%$ - $46 \%$, sisa nitrogen yang tidak diserap oleh tanaman tersebut akan mengalami volatilisasi, denitrifikasi, dan mengalami leaching. Unsur Nitrogen merupakan zat hara yang sangat diperlukan tanaman. Cara pemberian pupuk nitrogen mempengaruhi hilangnya nitrogen ke lingkungan berupa penguapan, dan pencucian, sehingga nitrogen yang dimanfaatkan tanaman berkurang (Palimbani, 2007).

Nitrogen dapat mengalami transformasi menjadi nitrat, nitrit, ammonium, ammonia. Bentukbentuk transformasi nitrogen di lingkungan adalah nitrifikasi, nitrate reduction dan denitrifikasi (Manahan, 2005; Wiederholt R \& B. Johnson, 2005). Nitrifikasi adalah oksidasi ammonia menjadi nitrat dan berlangsung pada kondisi aerob. Konversi dari N (-III) menjadi N (V) adalah proses yang sangat penting di air dan tanah.

Aplikasi pemberian pupuk $\mathrm{N}$ tunggal bisa menyebabkan peningkatan akumulasi $\mathrm{NO}_{3}$. dalam profil tanah dan pemulihan unsur $\mathrm{N}$ dalam tanah yang dibutuhkan tanaman berlangsung lambat. Aplikasi pupuk-N pada lahan pertanian dengan irigasi akan mengalami kehilangan dan larut dalam air irigasi atau air permukaan.

Nitrogen mempunyai peran penting bagi tanaman padi yaitu: mendorong pertumbuhan tanaman yang cepat dan memperbaiki tingkat hasil dan kualitas gabah melalui peningkatan jumlah anakan, pengembangan luas daun, pembentukan gabah, pengisian gabah, dan sintesis protein. Tanaman padi yang kekurangan nitrogen anakannya sedikit dan pertumbuhannya kerdil. Daun berwarna hijau kekuning - kuningan dan mulai mati dari ujung kemudian menjalar ke tengah helai daun.

\section{e. Fosfat $\left(\mathrm{PO}_{4}\right)$}

Fosfat dalam tanah merupakan hara yang tidak mobile, sebagian besar terikat oleh partikel tanah sebagian sebagai P-organik dan hanya sedikit yang dalam bentuk tersedia bagi tanaman. Pada tanah sawah ketersediaan P meningkat setelah penggenangan. Hal ini disebabkan karena penggenangan membantu terjadinya proses reduksi feri fosfat menjadi fero fosfat, hidrolisis aluminium, peningkatan kelarutan kalsium fosfat, dan netralnya reaksi tanah (Abdulrachman $d k k ., 2009$ ).

Serapan fosfat $(\mathrm{P})$ oleh akar tanaman hanya dapat berlangsung melalui mekanisme intersepsi akar dan difusi jarak pendek sehingga efisiensi pupuk $\mathrm{P}$ sangat rendah, yaitu berkisar antara $15 \%-20 \%$. Sejumlah P yang diserap tanaman hanya sebagian kecil yang hilang tercuci 
bersamaan dengan air perkolasi sebagian besar berubah menjadi $\mathrm{P}$ non mobile yang tidak tersedia bagi tanaman. Fenomena menunjukan bahwa pemberian pupuk fosfat secara terus menerus menyebabkan penimbunan $\mathrm{P}$ sehingga menurunkan respon terhadap pemupukan fosfat.

\section{Tujuan Penelitian}

Penelitian ini bertujuan untuk mengetahui kondisi kualitas air Irigasi Dumoga di Kabupaten Bolaang Mongondow Provinsi Sulawesi Utara.

\section{Metode Penelitian}

\section{a. Bahan dan Alat Penelitian}

Peralatan utama yang digunakan dalam penelitian ini adalah alat pengambilan sampel air: water sampler, ice box, GPS, $\mathrm{pH}$ meter, termometer, conductivitymeter, dan spectrophotometer: Peralatan yang digunakan untuk analisis konsentrasi TDS, TSS, nitrat, fosfat, natrium, kalsium, magnesium. Bahan penelitian adalah aquadest, tissue, label untuk menandai sampel, kamera serta alat tulis menulis.

b. Teknik Pengumpulan Data

Data primer diperoleh dengan mengambil data langsung di lapangan secara in situ : $\mathrm{pH}$, temperatur dan analisis di laboratorium yaitu untuk data kualitas air parameter TDS, TSS, nitrat, fosfat, natrium, kalsium, dan magnesium. Pengambilan sampel air mengacu pada APHA (2005) dan Hadi (2015). Pengambilan sampel air dilakukan dengan menggunakan metode composite sampling. Tahapan pengambilan sampel air dimulai dengan persiapan alat dan bahan, melakukan preparasi sampel di lapangan dan dianalisis di laboratorium kualitas air yang terakreditasi (Water Laboratory Nusantara Manado).

\section{c. Analisis data}

a. Analisis data menggunakan Metode Grafik untuk dapat mengevaluasi konsentrasi TDS, TSS, nitrat dan fosfat, serta memban- dingkan dengan Baku Mutu sesuai Peraturan Pemerintah Nomor 82 Tahun 2001 Kelas IV Tentang Pengelolaan Kualitas Air dan Pengendalian Pencemaran Air (KLH, 2001).

Kelas IV adalah air yang peruntukannya dapat digunakan untuk mengairi, pertanaman dan atau peruntukan lain yang mempersyaratkan mutu air yang sama dengan kegunaan tersebut.

b. Analisis data menggunakan perhitungan Sodium Absorption Ratio (SAR) dirumuskan sebagai berikut:

$$
S A R=\frac{N a}{\frac{\sqrt{C a+M g}}{2}}
$$

\section{Keterangan:}

SAR : Sodium Adsorption Ratio

$\mathrm{Na}^{+} \quad$ : Sodium/Natrium

$\mathrm{Ca}^{++}$: Kalsium

$\mathrm{Mg}^{++}$: Magnesium

Tabel 1. Klasifikasi Air Berdasarkan Nilai SAR

\begin{tabular}{|l|c|}
\hline SAR & Kualitas Air \\
\hline$<10$ & Baik sekali \\
$10-18$ & Baik \\
$18-26$ & Cukup \\
$>26$ & Kurang \\
\hline
\end{tabular}

Sumber : Mahida, 1981

\section{Hasil dan Pembahasan}

Pengukuran konsentrasi partikel terlarut (total dissolved solid/TDS) dan partikel tersuspensi (total suspended solid/ TSS) di Saluran Irigasi Dumoga telah dilakukan penelitian oleh Dinas Pertanian dan Peternakan Kabupaten Bolaang Mongondow bekerjasama dengan Fakultas Pertanian Universitas Sam Ratulangi Tahun 2016. Hasil analisis kedua parameter tersebut terhadap Baku Mutu PP 82 Tahun 2001 Kelas IV secara grafik terdapat pada Gambar 1. 


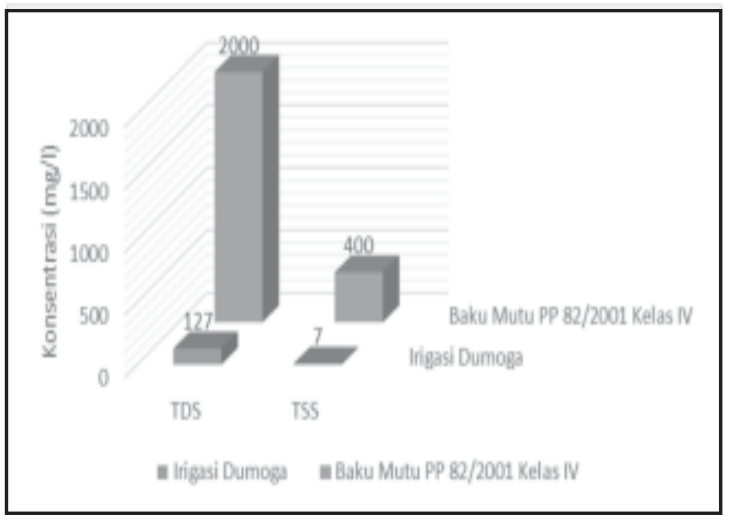

Gambar 1.

Konsentrasi Partikel Terlarut (Total Dissolved Solid/TDS) dan Partikel Tersuspensi (Total Suspended Solid/TSS) di Saluran Irigasi Dumoga Terhadap Baku Mutu PP 82 Tahun 2001 Kelas IV

Terdapat perbedaan konsentrasi antara konsentrasi Total Dissolved Solid/TDS) dan Partikel Tersuspensi (Total Suspended Solid/TSS) yaitu TDS memiliki konsentrasi lebih tinggi dari konsentrasi TSS. Hal tersebut antara lain disebabkan oleh adanya partikel-partikel organik dan anorganik yang terlarut dan masuk ke saluran Irigasi Dumoga yang antara lain disebabkan oleh adanya aliran permukaan erosi dan sedimentasi.

Konsentrasi nitrat dan fosfat di Saluran Irigasi Dumoga terhadap Baku Mutu PP 82 Tahun 2001 Kelas IV secara grafik terdapat pada Gambar 2 (Dinas Pertanian dan Peternakan Kabupaten Bolaang Mongondow dan Fakultas Pertanian UNSRAT, 2016).

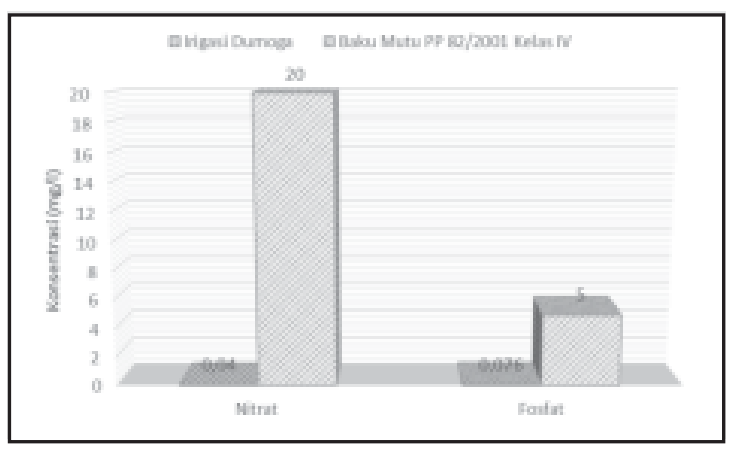

Gambar 2.

Konsentrasi Nitrat dan Fosfat di Saluran Irigasi Dumoga Terhadap Baku Mutu PP 82 Tahun 2001 Kelas IV
Hasil penelitian menunjukkan bahwa konsentrasi nitrat di Saluran Irigasi Dumoga adalah $0,040 \mathrm{mg} / 1$ dan konsentrasi fosfat $0,076 \mathrm{mg} / \mathrm{l}$. Sumber nitrat dan fosfat terbesar adalah dari outlet saluran irigasi persawahan yang memliki pertumbuhan vegetatif aktif. Terdapat perbedaan yang signifikan antara konsentrasi nitrat di outlet saluran irigasi yang tanaman padi di persawahan berada pada masa pertumbuhan aktif dimana kondisi ini juga menandakan masa pemupukan aktif (Wantasen, et al, 2014).

Walaupun demikian konsentrasi yang diperoleh memenuhi syarat sesuai Peraturan Pemerintah Nomor 82 Tahun 2001 Kelas IV Tentang Pengelolaan Kualitas Air dan Pengendalian Pencemaran Air (konsentrasi nitrat : $20 \mathrm{mg} / 1$; fosfat: $5 \mathrm{mg} / \mathrm{l}$ ).

Konsentrasi Sodium-dissolved $(\mathrm{Na})$ adalah 6,38 $\mathrm{mg} / \mathrm{l}$, konsentrasi Ca 0,76 mg/l dan konsentrasi $\mathrm{Mg}$ 0,27 mg/l. Nilai Sodium Absorption Ratio (SAR) adalah 8,89. Klasifikasi air irigasi berdasarkan nilai SAR, dibawah dari 10 baik sekali. Air berkadar sodium rendah (S1) dapat dipergunakan untuk irigasi pada hampir semua tanah dengan sedikit kemungkinan timbulnya bahaya yang dapat mengembangkan pertukaran sodium (Mahida, 1981).

\section{KESIMPULAN}

1. Konsentrasi Total Dissolved Solid/TDS $127 \mathrm{mg} /$ 1 dan Partikel Tersuspensi (Total Suspended Solid/TSS $7 \mathrm{mg} / \mathrm{l}$ memenuhi persyaratan baku mutu lingkungan air sesuai PP 82 Tahun 2001 Kelas IV (TDS: 2000 mg/l, TSS: 400 mg/l).

2. Konsentrasi nitrat $0,040 \mathrm{mg} / 1$, fosfat $0,076 \mathrm{mg} / \mathrm{l}$ memenuhi persyaratan baku mutu sesuai PP No 82/2001 Kelas IV ( $\mathrm{NO}_{3}: 20 \mathrm{mg} / \mathrm{l}$; Fosfat 5 $\mathrm{mg} / \mathrm{l})$.

3. Nilai Sodium Absorption Ratio (SAR) adalah 8,89 termasuk pada kategori baik sekali.

\section{SARAN}

Perlu dilakukan penelitian lanjutan mengenai kualitas air untuk kepentingan irigasi pertanian menggunakan Metode Sodium Absorption Ratio (SAR) di lokasi lain. 


\section{DAFTAR PUSTAKA}

Abdulrachman, S., H. Sembiring dan Suyanto, 2009. Pemupukan Tanaman Padi. http://www.litbang. pertanian.go.id/25-03-17.

APHA, 2005. Standard Methods For The Examination of Water and Waste Water, American public Health Association (APHA) 21 st edition. Method $10200 \mathrm{H}$ and 4500-NO2-B.

Ayers, R.S and D.W. Westcot, 1985. Water Quality For Agriculture, FAO, Rome Italy.

Dinas Pertanian dan Peternakan Kabupaten Bolaang Mongondow Bekerjasama dengan Fakultas Pertanian UNSRAT, 2016. Upaya pengelolaan lingkungan hidup dan Upaya pemantauan pengelolaan lingkungan hidup (UKL-UPL) Pencetakan Sawah Baru di Kecamatan Dumoga Kabupaten Bolaang Mongondow.

Effendi. H., 2003. Telaah Kualitas Air Bagi Pengelolaan Sumber Daya dan Lingkungan Peraira, . Kanisius, Yogyakarta.

Hadi. A., 2015. Pengambilan Sampel Lingkungan. Erlangga, Jakarta.

KLH, 2001. Peraturan Pemerintah Republik Indonesia Nomor 82 Tahun 2001 Tentang Pengelolaan Kualitas Air Dan Pengendalian Pencemaran Air, Jakarta.
Mahida, 1981. Pencemaran Air Dan Pemanfaatan Limbah Industri. Penerbit CV. Rajawali., Jakarta.

Manahan, S.E, 2005, Environmental Chemistry ( $8^{\text {th }}$ edition), Florida USA. CRC Press LLC,

Palimbani, 2007. Mengenal Pupuk Urea, dalam internet http://pusri.wordpress.com, 1-2-2011.

Sinaga. I. L, Jamilah, dan Mukhlis, 2013. Kualitas Air Irigasi Di Desa Air Hitam Kecamatan Limapuluh Kabupaten Batubara. http://download. portalgaruda.org/article..25-03-17.

Wiederholt R and B. Johnson, 2005. Nitrogen Behavior in the Environment, dalam internet http://www.ag.ndsu.edu/19-1- 2007.

Wantasen, S; Sudarmadji; R.R.H. Rumende; J.L. Rantung, 2014. Study of Residual Nitrogen Fertilizer in Outlet of Paddy Irrigation in Tondano Watershed North Sulawesi, International Conference on Ecohydrology (ICE) in Conjunction with the 22nd Meeting of IHP Regional Steering Committee (RSC) for South Asia and Pacific 2014 November 10 - 12, 2014, Yogyakarta - IndonesiaInternational Conference on Ecohydrology (ICE) 